\title{
DIRECT WRITTEN CORRECTIVE FEEDBACK ON INDONESIAN JUNIOR HIGH SCHOOL STUDENTS' RECOUNT TEXT COMPOSITION
}

\author{
Muhammad Irfan \\ Madrasah Aliyah Negeri Flores Timur \\ irfan.heni@gmail.com \\ https://doi.org/10.36052/andragogi.v8i2.171 \\ Diterima: 25 September 2020 | Disetujui: 24 Desember 2020 | Dipublikasikan: 26 Desember 2020
}

\begin{abstract}
Abstrak
Penelitian ini dimaksudkan untuk menginvestigasi sejauh mana balikan korektif tertulis langsung membantu siswa dalam mengurangi kesalahan siswa pada karangan teks recount. Penelitian kualitatif ini dilaksanakan di kelas VIII pada sebuah sekolah menengah pertama di Malang. Subyek dari penelitian ini adalah guru bahasa inggris dari kelas VIIIC pada sekolah tersebut dan enam siswa dari level kecakapan yang berbeda dari kelas ini. Penelitian ini menemukan bahwa: (1) Siswa membuat enam tipe kesalahan dalam karangan teks recount mereka setelah menerima balikan korektif tertulis langsung, (2) Balikan korektif tertulis langsung membantu siswa dengan kemampuan rendah pada tingkatan yang kecil dalam mengurangi kesalahan mereka pada karangan teks, (3) Balikan korektif tertulis langsung membantu siswa dengan kemampuan sedang pada tingkatan yang kecil dalam mengurangi kesalahan mereka pada karangan teks recount, (4) Balikan korektif tertulis langsung membantu siswa dengan kemampuan tinggi pada tingkatan yang sedang dalam mengurangi kesalahan mereka pada karangan teks recount.
\end{abstract}

Kata Kunci: Balikan Korektif Tertulis Langsung, Siswa Sekolah Menengah Pertama, Karangan Teks Recount

\begin{abstract}
[DIRECT WRITTEN CORRECTIVE FEEDBACK ON JUNIOR HIGH SCHOOL STUDENTS' RECOUNT TEXT COMPOSITION]. This present study is aimed to investigate the extent to which direct written corrective feedback (CF) assists students in minimizing students' errors on recount text composition. This qualitative study was carried out in class VIII C at a junior high school in Malang. The Subjects of this study were the English teacher from class VIII C at the school and six students from three different levels of proficiency in this class. This present study found that: (1) Students made six types of errors on their recount text compositions after receiving direct written CF, 2) Direct written $\mathrm{CF}$ assists low proficiency students to a little extent in minimizing their errors on recount text compositions, (3) Direct written CF assists average proficiency students to a little extent in minimizing their errors on recount text compositions, (4) Direct written CF assists high proficiency students to a medium extent in minimizing their errors on recount text compositions.
\end{abstract}

Keywords: Direct Written Corrective Feedback, Junior High School Students, Recount Text Composition

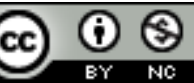

This work is licensed under a Creative Commons Attribution-NonCommercial 4.0 International License 


\section{INTRODUCTION}

$\tau$ eacher's feedback in a writinglearning process plays an important role in helping students to improve their accuracy in writing. Muncie (2000, p. 52) stated that feedback was vital to writing and in helping learners to improve their writing skills. The appropriate feedback given by the teacher can make students know and realize their errors, so they can correct them based on the feedback given. According to Ellis (2009, p. 3), "feedback is viewed as a means of fostering learner motivation and ensuring linguistic accuracy".

Corrective feedback (CF) is one type of negative feedback. It can be oral or written and as a fundamental part of teaching especially in writing. It is a reaction to inaccurate oral or written output or in other words, it is the response to learners' incorrect language use (Pawlak, 2014, p. 35) .

The application of direct CF on students' writing text is not something new. Studies that are related to the application of direct CF in relation to students' writing text can be seen from a study by Guénette and Lyster (2013). Their study revealed that a group of pre-service ESL teachers in the context of secondary education in Quebec applied mostly on direct correction feedback strategies when providing $C F$ on writing to $L 2$ learners. The next study that was carried out by Kamberi (2013) showed that the majority of the students participating in the study prefer teacher feedback compared to peer feedback. From all the feedback strategies that have been used in the study, the most preferred by students seems to be direct CF since students want the correction to be there.

The studies on the application of CF showed that direct written CF actually has been applied in students' writing and students are also familiar with direct CF application. The study also revealed that the students also preferred this type of feedback when dealing with their errors in writing.

There are some previous studies related to direct written CF on students' writing (Bitchener, 2008; Bitchener and Knoch, 2009; Vyatkina, 2010; Shintani, Ellis, and Suzuki 2014; and Rahmawati, 2013). The first previous study was carried out by Bitchener (2008) . The study found that direct written CF had a significant effect on improving students' accuracy in the use of English articles on writing.

The second previous study is conducted by Bitchener and Knoch (2009) found the same result that direct error correction alone may be as effective as direct error corrective with a written meta-linguistic explanation or direct error corrective with both written and spoken meta-linguistic explanation in improving students' writing accuracy.

The third study by Vyatkina (2010) found that direct CF could improve students' accuracy in redrafting their writing. The direct CF led to slightly higher correction rates for selected errors.

The fourth study conducted by Shintani et al. (2014)found that direct CF followed by revision proved the most effective type of feedback. The results also indicate that directly correcting the errors learners make with respect to a complex syntactical structure is more beneficial than giving them a metalinguistic explanation and the effectiveness of the direct CF proved longer lasting than the metalinguistic feedback.

The last previous study by Rahmawati (2013) found that direct CF can make the tendency of the students to rewrite their grammatical errors because of the absence of a student-teacher consensus about the meaning of the teacher's markings. The teacher preferred the direct CF strategy over other CF strategies in correcting students' errors.

The findings from several previous studies that have been explained above reveal that direct CF can lead to the improvement in students' writing accuracy (Bitchener, 2008; Bitchener and Knoch, 2009; Vyatkina, 2010; Shintani, Ellis, and Suzuki 2014). In other words, direct CF is effective to help the students in minimizing their errors in their writing. Although the different results from Rahmawati (2013) study showed that direct CF could lead to the students' tendency to rewrite their errors. Yet, the finding of her study revealed that the confusion and the tendency of the students in rewriting their errors mainly caused by the absence of a student-teacher consensus about 
the meaning of the teacher's markings. The findings also showed that the error categories that have been analyzed in those studies are varied and did not specify in some specific language features criteria that are related to the type of text that they give to the students.

In addition, a study related to error reduction by using computer assistance by Fakhrudin and Munir (2014) found that wordprocessing helped the student to decrease their errors. The students also gave a positive response to the use of word-processing in the writing class. The use of word-processing in students' writing could decrease or minimize errors in their writing.

A study by Suarman (2013) on nine students of the high, medium, and low achievers of junior high school about written CF given by the teacher in their writings found that all students performed better writing accuracy in revision text. Students made fewer errors on their writing.

A study by (Nasrullah, 2014) about students' errors showed the quality of students' work because the teacher used them as an indicator of writing quality. Hence, it is very likely that students of low proficiency commit more errors. The finding also showed that the teacher's written feedback enabled the students to minimize their grammatical errors.

Yet, the findings from previous studies showed that direct written CF was not applied to all types of errors that the students made in their writing. Direct written CF just covered the errors selected by the teacher. In addition, direct written $\mathrm{CF}$ was not applied to the specific genre of the text, and all the errors that the students made in their writing were not included. Therefore, it is important to conduct a study related to the application of direct written CF on the specific genre of text and the type of errors that students made on their writing in order to know which type of errors the students made on their writing and the extent to which direct written CF assist the students in improving their accuracy and minimizing the errors on their writing.

This study has been aimed to investigate the extent to which direct written CF assists students in minimizing their errors on recount text composition. The current study has been guided by the following research questions:

1. What type of errors do the students make on their recount text compositions after direct written CF given by the teacher?

2. To what extent does direct written CF assist low proficiency students in minimizing their errors on recount text composition?

3. To what extent does direct written CF assist average proficiency students in minimizing their errors on recount text composition?

4. To what extent does direct written CF assist high proficiency students in minimizing their errors on recount text composition?

CF is an integral part of an English teaching and learning process. It can be used to describe teachers' response to learners' inaccurate spoken and written output (Pawlak, 2014 , p. ix). CF refers to the feedback that learners receive on the linguistic errors they make in their oral or written production in a second language (L2) (Sheen \& Ellis, 2011, p. 593). Chaudron (1977, p. 31), cited in Panova and Lyster (2002) described it as any reaction of the teacher which clearly transforms, disapprovingly refers to, or demands the improvement of the learner utterance. According to Ellis et al. (2006, p. 340), CF took the form of responses to learner utterances that contain an error. The responses can consist of (a) an indication that an error has been committed, (b) provision of the correct target language form or (c) metalinguistic information about the nature of the error, or any combination of these. CF may be defined as information from any source regarding the learner's L2 performance in order to stimulate acquisition (Cornillie et al., 2012, p. 50). In writing, CF on the form is concerned with any incorrect grammatical or lexical use of the target language (Guénette \& Lyster, 2013, p. 130)

There are at least two main roles of corrective feedback in writing. First, CF helps students to improve their writing. It enables students to read and understand the problems and use it to improve future writing. CF can 
increase students' awareness of errors. It helps them to avoid and correct their errors in writing. According to Leng (2014, p. 390), written feedback is able to help students improve their writing and at the same time assist students in producing a written text which contains minimum errors and maximum clarity. Second, CF can develop students' writing abilities. Coffin et al. (2003, p. 104) stated that CF can support students' writing development.
It helps students to know their strengths and weaknesses in writing through feedback given by the teacher. The students can develop and revise their next writing through CF from the teacher.

There are several types of written CF according to Ellis (2008, p. 98). The types of written CF based on Ellis' typology are shown in Table 1.

Table 1. Typology of written corrective feedback types

\begin{tabular}{|c|c|}
\hline Types of CF & Description \\
\hline Direct CF & The teacher provides the student with the correct form. \\
\hline Indirect CF & $\begin{array}{l}\text { The teacher indicates that an error exists but does not provide the } \\
\text { correction. }\end{array}$ \\
\hline Metalinguistic CF & $\begin{array}{c}\text { The teacher provides some kind of metalinguistic clue as to the } \\
\text { nature of the error. }\end{array}$ \\
\hline $\begin{array}{l}\text { The focus of the } \\
\text { feedback }\end{array}$ & $\begin{array}{l}\text { This concerns whether the teacher attempts to correct all (or most) of } \\
\text { the students' errors or selects one or two specific types of errors to } \\
\text { correct. }\end{array}$ \\
\hline Electronic feedback & $\begin{array}{l}\text { The teacher indicates an error and provides a hyperlink to a } \\
\text { concordance file that provides examples of correct usage. }\end{array}$ \\
\hline Reformulation & $\begin{array}{l}\text { This consists of a native speaker's reworking of the students' entire text } \\
\text { to make the language seem as native-like as possible while keeping } \\
\text { the content of the original intact. }\end{array}$ \\
\hline
\end{tabular}

The important point of the typology of written CF provided by Ellis in Table 1 gives a basis for a systematic approach to investigate written CF for teachers and researchers. The teachers and researchers are able to systematically identify the various options available for correcting students' writing as a basis for both designing studies and for pedagogical decision making. Ellis (2008, p. 97) argued that identifying the options in a systematic way is essential for both determining whether written CF is effective and, if it is, what kind of CF is most effective.

Based on the observation on the situation in the class before the application of direct written CF, many of the students had difficulties in improving their accuracy in writing. They still made errors in their writing and did not understand how to correct the errors. Consequently, their writing qualities were not so good. The improvement of accuracy in their writing is needed so they can increase their writing ability. Direct written CF is needed to solve the problems the students face in their writing. Accordingly, the teacher needs to apply direct written CF so the students can improve their writing accuracy and minimize the errors in their writing.

\section{RESEARCH METHOD}

In this study, the writer employs one type of qualitative research that is called basic qualitative study or basic interpretative study since it describes and interprets a phenomenon or process (Ary et al., 2010, p. 452). Additionally, Ary et al. (2010, p. 636) gives the definition of this type of research as a form of qualitative research that provides a descriptive account targeted to understanding a phenomenon using data that may be collected in a variety of ways.

This study was carried out in class VIII C at a junior high school Malang located in Malang. This school was chosen because it was one of the favorite schools in Malang city and the 
possibility to get school permission to conduct a study in this school. In addition, the English teacher in this school also applied direct written CF to correct students' errors in writing. The study was set in a natural setting with no intervention on any situation in the class. It is in line with what had been stated by DonYei (2007, p. 38) that qualitative research took place in the natural setting, without any attempts to manipulate the situation under study. The writer wanted to give a real description of the phenomenon under study. According to McKenney et al. (2006, p. 84) , the benefits of conducting research in authentic settings would seem obvious: the more realistic the research setting, the more the data reflected reality.

The subjects of this study were the English teacher from class VIII $C$ at the school and six students from three different levels of proficiency (two from a low level, two from average level, and two from a high level) of this class. The class was chosen as the place to conduct the study because the topic of the lesson is recount text and the teacher applied direct written CF to this class. In addition, the teacher is also the English in this class so it can make it easier to get the information about the application of direct written CF feedback. Six students were also chosen as the subjects of this study to represent the three-level of proficiencies needed in this study. To know the students' level of proficiency, the teacher was asked for information about students' ability in writing to decide which one is the low, average, and high level based on their writing skills.

The data in this study was obtained from students' recount text compositions that they composed before direct written CF given by the teacher and the second recount text compositions that students composed after direct written CF given by the teacher. The data from students' recount text compositions before and after direct written CF has given were used to answer research questions two, three, and four on this study. The data from students' recount text compositions after direct written CF has given are used to answer research question one on this study.
There were seven error categories or types according to language features of recount text that used to analyze the errors that students made on their recount text compositions: nouns and pronouns errors, action verbs errors, past tense errors, conjunctions errors, time connectives errors, adverbs and adverbial phrases errors, and adjectives errors. After direct written CF given by the teacher, the students were asked to compose the second recount text compositions in order to know the extent to which direct written CF assists them in minimizing their errors on recount text compositions. The second source of the data was the teacher's written CF on students' recount text compositions. The feedback was given by the teacher on the error categories that had been used in this study by giving the correct form of the errors that students made on their recount text compositions. The third data source in this study was acquired from the field notes through observation on students' works the writer conducted in the classroom during the writing learning process was taking place.

Students' recount text composition before and after feedback is given was analyzed to answer the research questions that had been formulated in this study. First, six recount text compositions from six students that had been categorized as low, average, and high proficiency were analyzed to know errors on their first composition. After analyzing errors in their first composition (compositions before feedback is given), their second compositions (compositions after feedback given) were analyzed also to know errors on their second compositions. Then, after analyzing errors on their second compositions, so the errors on their first and second compositions were described and explain to answer the research questions one to four.

\section{RESULTS AND DISCUSSION}

\section{Results}

After conducting data analysis on students' recount text compositions, the writer found some type of errors that students made after direct written CF given by the teacher. The errors on this study were limited only on seven error types according to language features of 
recount text, those are (1) noun and pronoun errors; (2) action verb errors; (3) past tense errors; (4) conjunction errors; (5) time connective errors; (6) adverb and adverbial phrase errors; (7) adjective errors.

The classification of students' errors on recount text composition according to language features of recount text showed that there were six types of errors that the students made on their recount text compositions. Types of error that the students made on their second text compositions after direct written CF given by the teacher were noun and pronoun errors, action verb errors, past tense errors, conjunction errors, adverb and adverbial phrase errors, and adjective errors.

The explanation of the errors that the students made on their recount text compositions after direct written CF given by the teacher was as follows.

1. Noun and pronoun errors

Noun and pronoun errors were related to noun and pronoun incorrect, omitted, or unnecessary. The errors that students made related to the incorrect noun and pronoun, capital and lower case letter errors, word order, plural form errors, unnecessary word. For example:

- When we arrived in Ketapang vort

- my Friend's mango tree

- Which contained by giant statues. those statues ...

- My sister and I went to the shop shoe.

- a lot of cute turtle

- it's was unique number

2. Action verb errors

Action verb errors related to action verbs incorrect, omitted, or unnecessary. The errors that students made related to the incorrect noun and pronoun, capital letter errors, omitted words. For example:

- the trunk where I stand broken

- I Fell out of a mango tree

- We immediately_to

3. Past tense errors

Past tense errors related to past tense incorrect, omitted, or unnecessary. The errors that students made related to the incorrect past tense form and omitted word. For example:
- I am quite happy with this

- My heart__very happy

4. Conjunction errors

Conjunction errors related to conjunction incorrect, omitted, or unnecessary. The errors that students made related to the incorrect conjunction. For example:

- Becouse no one dared to climb the three

5. Adverb and adverbial phrase errors

Adverb and adverbial phrases errors related to incorrect, omitted, or unnecessary adverbs and adverbial phrases. The errors that students made related to the incorrect noun and pronoun, capital letter errors, and word order. For example:

- At 7 a clock

- we Finally got to see a sign

- at there very crowded

6. Adjective errors

Adjective errors related to incorrect, omitted, or unnecessary adjectives. Some adjective errors still could be found on the student's writing. The errors that students made related to the incorrect noun and pronoun, capital letter errors, word order. For example:

- the unihabited island

- my Favorite place

- a lot of cute turtle and adorable

There were six types of errors that students made on their recount text compositions after direct written CF given by the teacher. Type of errors that the students made on their recount text compositions after direct written CF given by the teacher were (1) noun and pronoun errors; (2) action verb errors; (3) past tense errors; (4) conjunction errors; (5) adverb and adverbial phrase errors; and (6) adjective errors.

Recount text compositions of low proficiency students were analyzed to answer the second research question on this present study. First recount text compositions from low proficiency students before direct written CF given by the teacher, the second recount text compositions from low proficiency students with direct written $C F$, and third recount text compositions that the students composed after receiving direct written CF were analyzed and 
compared in order to know the extent to which direct written CF assisted low proficiency students in minimizing their errors on recount text compositions.

Low proficiency students' recount text compositions were analyzed and compared based on the errors that they made on their first recount text compositions, direct written CF on the errors on students' recount text compositions, and their final drafts that the low proficiency students composed after receiving direct written $\mathrm{CF}$ from the teacher in order to know the extent to which direct written CF assisted low proficiency students in minimizing the errors that they made on their recount text compositions.

There were several errors that low proficiency students made on their $\mathrm{T} 1$ compositions. The errors that low proficiency students made on their $\mathrm{T} 1$ compositions were classified to know the type of errors that they made on their $\mathrm{T} 1$ compositions. There were seven types of errors that the students made on their T1 compositions. Type of errors that the low proficiency students made on their first recount text compositions were noun and pronoun errors, action verbs errors, past tense errors, conjunction errors, time connective errors, adverb and adverbial phrases errors, and adjective errors.

On their recount text compositions that had been given direct written CF from the teacher, there were several errors that had been given direct written CF from the teacher. The errors that had been given direct written CF according to the language features of recount text were as follows:

\section{Direct written CF on noun and pronoun errors}

The following excerpts showed the direct written CF on noun and pronoun errors on low proficiency students' recount text compositions.

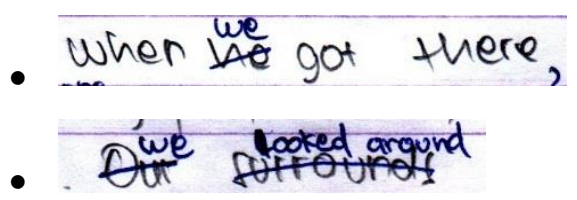

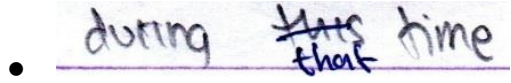

- shert

- for exáple

2. Direct written $\mathrm{CF}$ on action verb errors

The excerpts from first recount text compositions showed the action verbs errors made by low proficiency students and direct written $\mathrm{CF}$ on the errors by the teacher. The following excerpts showed direct written $\mathrm{CF}$ on action verb errors on student's writings.
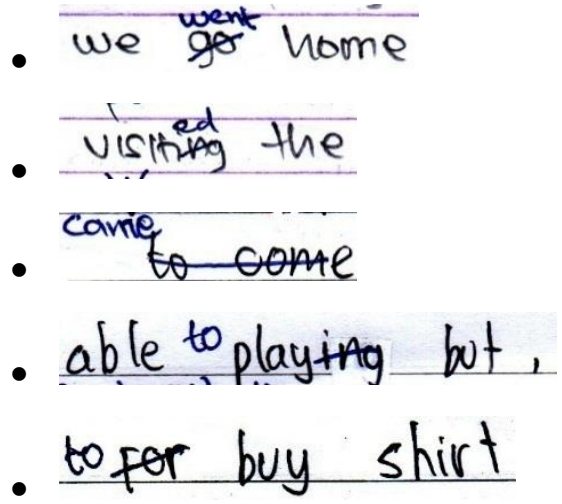

3. Direct written $\mathrm{CF}$ on past tense errors

Direct written CF given by the teacher on past tense errors low proficiency students' recount text compositions could be seen in the following excerpts.

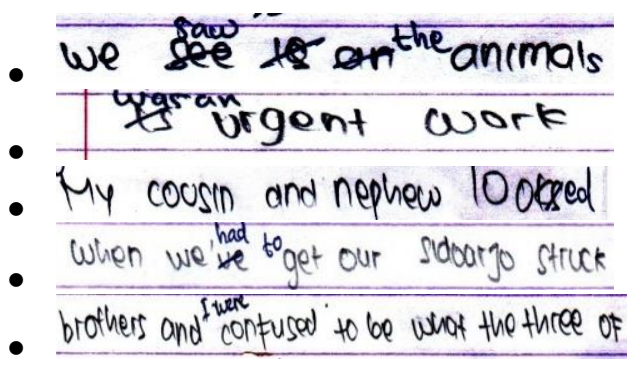

4. Direct written CF on conjunction errors

Direct written CF on conjunction error on low proficiency students' recount text composition could be seen in the following excerpts.

- at 3 pm until 6 pr.

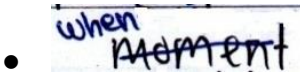

5. Direct written CF on time connective errors 
Direct written CF on time connective error on low proficiency student's recount text composition could be seen in the following excerpt.

\section{- after that,}

6. Direct written CF on adverb and adverbial errors

The excerpt below showed direct written CF on adverb and adverbial phrase error on low proficiency student's recount text composition.<smiles>CCCC#CC(C)C</smiles>

7. Direct written $\mathrm{CF}$ on adjective errors

In the excerpt below, direct written CF was given by the teacher on an adjective error on low proficiency student's recount text composition.

\section{- unbeorate during}

It could be concluded from the excerpts above that direct written $\mathrm{CF}$ had been given by the teacher low proficiency students' errors on their recount text compositions. Direct written CF was given by the teacher on seven error types according to the language features of recount text such as noun and pronoun errors, action verbs errors, past tense errors, conjunction errors, time connective errors, adverb and adverbial phrases errors, and adjective errors. In addition, direct written CF was given by the teacher on students' errors with crossing out the errors and providing the correct form above or near the errors, adding the correct words or phrases above or near the omitted words or phrases, crossing out the unnecessary words or phrases on students' compositions, and circling the error on word order and showing the correct word order on students' compositions.

The final draft (T2) compositions from low proficiency students were analyzed also in order to know the extent to which direct written CF given by the teacher assisted low proficiency students in minimizing the errors on their recount text compositions after direct written CF given by the teacher.

The analysis of low proficiency students' final draft (T2) compositions above had shown that the errors still could be found in students' works. After classifying the errors that the students made on their final draft, it could be seen that there were several types of errors that students made on their final draft after receiving direct written $\mathrm{CF}$ from the teacher. Type of errors that low proficiency students made on their final draft (T2) composition were noun and pronoun errors, action verbs errors, past tense errors, conjunction errors, adverb and adverbial phrases errors, and adjective errors.

In summary, there were seven types of errors that low proficiency students made on their T1 compositions: noun and pronoun errors, action verbs errors, past tense errors, conjunction errors, time connective errors, adverb and adverbial phrases errors, and adjective errors. The teacher had given direct written CF on low proficiency students' errors on their $\mathrm{T} 1$ compositions. There were seven error types that had been given direct written CF by the teacher: noun and pronoun errors, action verbs errors, past tense errors, conjunction errors, time connective errors, adverb and adverbial phrases errors, and adjective errors. On low proficiency students' final drafts that the students composed after receiving direct written $\mathrm{CF}$ from the teacher, there were six types of errors that the students made on their recount text compositions: noun and pronoun errors, action verbs errors, past tense errors, conjunction errors, adverb and adverbial phrases errors, and adjective errors.

Low proficiency students still made repeated errors on their second recount text composition after receiving direct written $\mathrm{CF}$ on the first recount text compositions. Although the errors were still repeated and happened on their second recount text compositions, the students also could minimize their errors on the T2 compositions. Low proficiency students made to a little error on their second recount text compositions because some errors that had been given direct written CF were repeated again by the students on their second compositions and the students could just minimize the errors on one type of errors.

The results of the study showed that direct written CF given by the teacher assisted the low proficiency students in minimizing the errors in 
their second recount text compositions (T2). The students could minimize their errors in their recount text compositions. Although the errors minimized did not to a large extent, yet the results also proved that direct written CF assisted the low proficiency students in minimizing their errors on their second recount text compositions.

In answering the third research question on this present study, the recount text compositions from average proficiency students were analyzed to know the extent to which direct written CF assisted average proficiency students in minimizing their errors on recount text compositions. Recount text compositions from average proficiency students were the first text that they composed before direct written CF given by the teacher. Recount text that the average proficiency students made then given direct written CF by the teacher in order to the students could avoid the errors in their further text that they would write. After they got direct written $\mathrm{CF}$, the students wrote the new recount text in order to know the extent to which direct written CF assisted average proficiency students in minimizing the errors on their recount text compositions.

Average proficiency students' recount text compositions were analyzed and compared based on the errors that they made on their first recount text compositions, direct written CF on the errors on students' recount text compositions, and their final drafts that the average proficiency students composed after receiving direct written $\mathrm{CF}$ from the teacher in order to know the extent to which direct written CF assisted average proficiency students in minimizing the errors that they made on their recount text compositions.

There were several errors that average proficiency students made on their $\mathrm{T} 1$ compositions. The errors that average proficiency students made on their T1 compositions were classified to know the type of errors that they made on their $\mathrm{T} 1$ compositions. There were seven types of errors that the students made on their $\mathrm{T} 1$ compositions. Type of errors that the average proficiency students made on their first recount text compositions were noun and pronoun errors, action verbs errors, past tense errors, conjunction errors, time connective errors, adverb and adverbial phrases errors, and adjective errors.

On their recount text compositions that had been given direct written $\mathrm{CF}$ from the teacher, there were several errors that had been given direct written $\mathrm{CF}$ from the teacher. The errors that had been given direct written CF according to the language features of recount text were as follows:

1. Direct written CF on noun and pronoun errors

Direct written CF had been given by the teacher on noun and pronoun errors on average proficiency students' recount text compositions. The excerpts below showed direct written CF given by the teacher related to noun and pronoun errors, unnecessary word or phrases, word order, omitted pronoun, and plural forms that average proficiency students made on first recount text compositions.
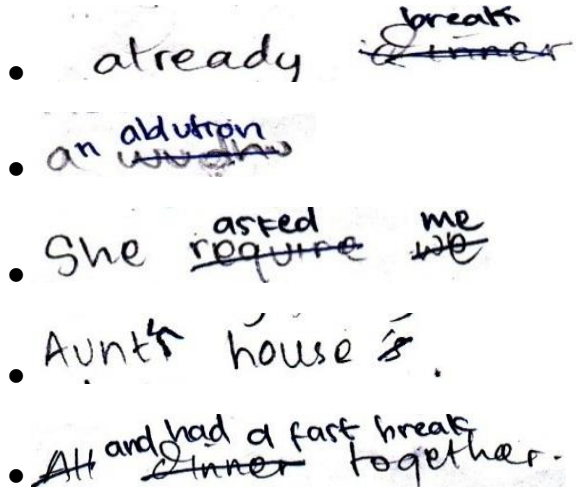

2. Direct written CF on action verb errors

Direct written CF on average proficiency students' recount text compositions could be seen in the following excerpts. The following excerpts showed direct written CF on incorrect use of action verb, omitted word or phrases errors could be seen on the excerpts below.

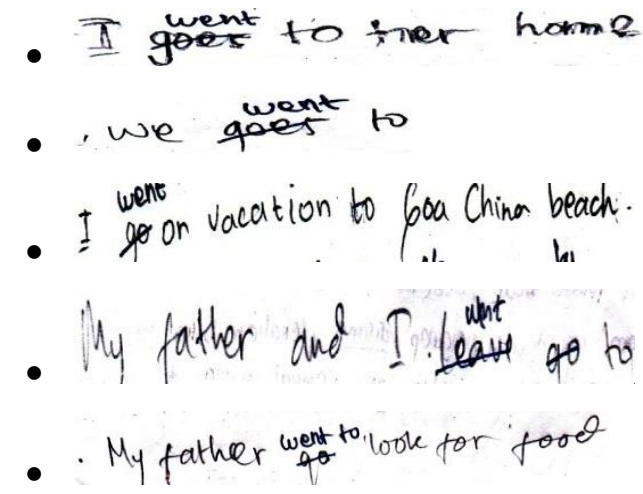

3. Direct written CF on past tense errors 
Direct written $\mathrm{CF}$ on the past tense errors by average proficiency students on their recount text compositions could be seen in the following excerpts.

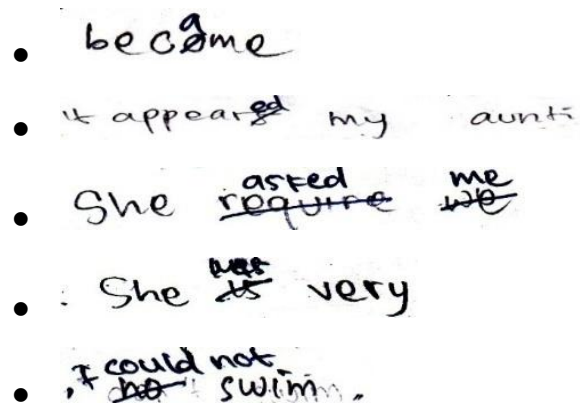

4. Direct written CF on conjunction errors

Direct written $\mathrm{CF}$ on conjunction errors on average proficiency students' compositions could be seen in the following excerpts.

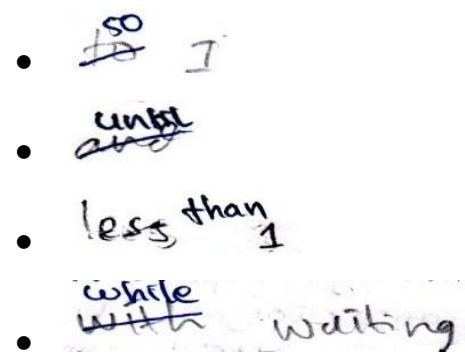

5. Direct written CF on adverb and adverbial phrase Errors

The excerpt below showed direct written CF on adverb and adverbial errors on average proficiency students' recount text compositions.

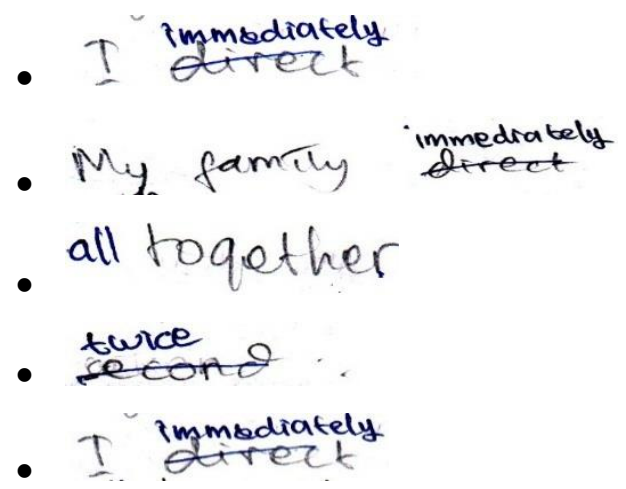

6. Direct written $\mathrm{CF}$ on adjective errors

In the excerpt below, direct written CF was given by the teacher on unnecessary use of an adjective on a sentence with crossing out the unnecessary adjective.

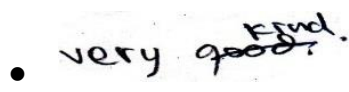

\section{- very delicius. \\ - Each trme My family and I}

It could be concluded from the excerpts above that direct written CF had been given by the teacher average proficiency students' errors on their recount text compositions. Direct written $\mathrm{CF}$ is given by the teacher only on six error types according to the language features of recount text such as noun and pronoun errors, action verbs errors, past tense errors, conjunction errors, adverb and adverbial phrases errors, and adjective errors. In addition, direct written CF was given by the teacher on students' errors with crossing out the errors and providing the correct form above or near the errors, adding the correct words or phrases above or near the omitted words or phrases, crossing out the unnecessary words or phrases on students' compositions, and circling the error on word order and showing the correct word order on students' recount text compositions.

The final draft (T2) compositions from average proficiency students were analyzed also in order to know the extent to which direct written CF given by the teacher assisted average proficiency students in minimizing the errors on their recount text compositions after direct written CF given by the teacher.

The analysis of average proficiency students' final draft (T2) compositions above had shown that the errors still could be found in students' works. After classifying the errors that the students made on their final draft, it could be seen that there were several types of errors that students made on their final draft after receiving direct written CF from the teacher. Type of errors that average proficiency students made on their final draft (T2) composition were noun and pronoun errors, action verbs errors, past tense errors, conjunction errors, and adverb and adverbial phrases errors.

In summary, there were seven types of errors that average proficiency students made on their T1 compositions: noun and pronoun errors, action verbs errors, past tense errors, conjunction errors, time connective errors, adverb and adverbial phrases errors, and adjective errors. Direct written CF had been given by the teacher on average proficiency 
students' errors on their T1 compositions. Among seven error types that had been made by average proficiency students on their first recount text compositions, the teacher only gave direct written CF on six error types on students' recount text compositions. Six types of errors that had been given direct written CF by the teacher: noun and pronoun errors, action verbs errors, past tense errors, conjunction errors, adverb and adverbial phrases errors, and adjective errors. On average proficiency students' final drafts that the students composed after receiving direct written $\mathrm{CF}$ from the teacher, there were five types of errors that the students made on their recount text compositions: noun and pronoun errors, action verbs errors, past tense errors, conjunction errors, adverb and adverbial phrases errors.

Average proficiency students still made repeated errors on their second recount text composition after receiving direct written CF on the first recount text compositions. Although the errors were still repeated and happened on their second recount text compositions, the students also could minimize their errors on the T2 compositions. Average proficiency students made to little extent errors minimized on their second recount text compositions because some errors that had been given direct written CF were repeated again by the students on their second compositions and the students could just minimize the errors on two types of errors.

The results of the study showed that direct written CF given by the teacher assisted the average proficiency students in minimizing the errors on their second recount text compositions (T2). The students could minimize their errors on their recount text compositions after receiving direct written CF from the teacher although some errors still made by the students on their compositions.

In answering the fourth research question on this present study, the recount text compositions from high proficiency students were analyzed to know the extent to which direct written CF assisted high proficiency students in minimizing their errors on recount text compositions. Recount text compositions from high proficiency students were the first text that they composed before direct written CF given by the teacher. Recount text compositions that the high proficiency students made then given direct written CF by the teacher. After they got direct written $C F$, the students wrote the new recount text.

On high proficiency students' recount text compositions that had been given direct written CF from the teacher, there were several errors that had been given direct written CF from the teacher. The errors that had been given direct written CF on high proficiency students' recount text compositions according to the language features of recount text were as follows:

1. Direct written $\mathrm{CF}$ on noun and pronoun errors

Direct written CF given by the teacher on noun and pronoun errors on high proficiency students' recount text compositions could be seen in the following excerpts shown.

$$
\begin{aligned}
& \text { - I together with } \\
& \text { - Inthe } 3 r d \text { day of Eid. } \\
& \text { - Eid yedifir together. } \\
& \text { - last day before Ied } \\
& \text { - me and My family ardI. }
\end{aligned}
$$

2. Direct written CF on action verb errors

The following excerpts showed direct written CF on action verb errors on high proficiency students' recount text compositions.
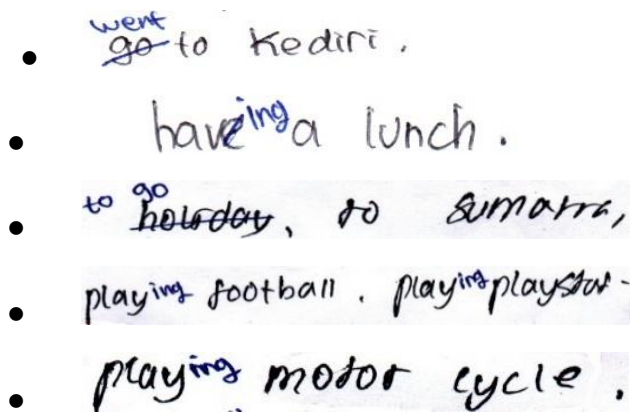

\section{Direct written CF on past tense errors}

Direct written CF given by the teacher on past tense errors high proficiency students' recount text compositions could be seen in the following excerpts. 
- At there we searched

- searched for hotel.

- we had a holidag

- we celebrated

- We stayed

4. Direct written CF on conjunction errors

Direct written CF on conjunction error on high proficiency students' recount text composition could be seen in the following excerpts.

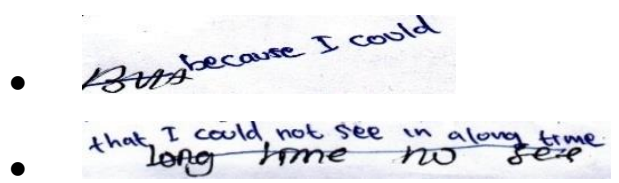

5. Direct written CF on time connective errors

Direct written CF on time connective error on high proficiency student's recount text composition could be seen in the following excerpt.

$$
\begin{aligned}
& \text { On the next day } \\
& \text { - Iommarow }
\end{aligned}
$$

6. Direct written CF on adverb and adverbial errors

The excerpt below showed direct written CF on adverb and adverbial phrase error on high proficiency student's recount text composition.

$$
\begin{aligned}
& \text { - At there, toomany } \\
& \text { - At there we had a holiday there } \\
& \text { - Here is very funny there }
\end{aligned}
$$

\section{Direct written $C F$ on adjective errors}

in the excerpt below, direct written CF was given by the teacher on an adjective error on high proficiency student's recount text composition.

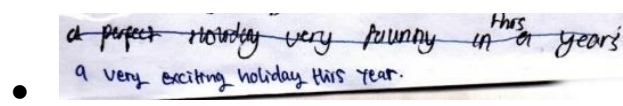

It could be concluded from the excerpts above that direct written CF had been given by the teacher high proficiency students' errors on their recount text compositions. Direct written CF was given by the teacher on seven error types according to the language features of recount text such as noun and pronoun errors, action verbs errors, past tense errors, conjunction errors, time connective errors, adverb and adverbial phrases errors, and adjective errors. In addition, direct written CF was given by the teacher on students' errors with crossing out the errors and providing the correct form above or near the errors, adding the correct words or phrases above or near the omitted words or phrases, crossing out the unnecessary words or phrases on students' compositions, and circling the error on word order and showing the correct word order on students' compositions.

The final draft (T2) compositions from high proficiency students were analyzed also in order to know the extent to which direct written CF given by the teacher assisted high proficiency students in minimizing the errors on their recount text compositions after direct written CF given by the teacher.

The analysis of high proficiency students' final draft (T2) compositions above had shown that the errors still could be found on high proficiency students' recount text compositions. After classifying the errors that the students made on their final draft, it could be seen that there were several types of errors that students made on their final draft after receiving direct written $\mathrm{CF}$ from the teacher. Type of errors that high proficiency students made on their final draft (T2) composition were noun and pronoun errors, action verbs errors, past tense errors, adverb and adverbial phrases errors.

In summary, there were seven types of errors that high proficiency students made on their T1 compositions: noun and pronoun errors, action verbs errors, past tense errors, conjunction errors, time connective errors, adverb and adverbial phrases errors, and adjective errors. Direct written CF had been given by the teacher on high proficiency students' errors in their T1 compositions. Direct written CF is given by the teacher on seven types of errors in students' recount text compositions. Seven types of errors that had been given direct written CF by the teacher were noun and pronoun errors, action verbs errors, past tense 
errors, conjunction errors, time connective errors, adverb and adverbial phrases errors, and adjective errors. On high proficiency students' final drafts that the students composed after receiving direct written $\mathrm{CF}$ from the teacher, there were four types of errors that the students made on their recount text compositions: noun and pronoun errors, action verbs errors, past tense errors, and adverb and adverbial phrases errors.

High proficiency students still made repeated errors on their second recount text composition after receiving direct written $\mathrm{CF}$ on the first recount text compositions. Although the errors were still repeated and made on their final draft after receiving direct written $\mathrm{CF}$ from the teacher, the high proficiency students also could minimize their errors on the T2 compositions. High proficiency students made to medium extent errors minimized on their recount text compositions because some errors that had been given direct written CF were repeated again by the students on their recount text compositions and the students could minimize the errors on three types of errors.

The results of the study showed that direct written $\mathrm{CF}$ given by the teacher assisted the high proficiency students in minimizing the errors on their second recount text compositions (T2). The students could minimize their errors on their recount text compositions after receiving direct written CF from the teacher although some errors still made by the students on their compositions.

\section{Discussion}

Findings show that having been given direct written CF by the teacher, students still made some errors in their recount text compositions. The errors that the students made on their recount text compositions could be classified into six types of errors according to the language features of recount text. Types of errors that the students made on their recount text compositions after direct written CF given by the teacher were noun and pronoun errors, action verb errors, past tense errors, conjunction errors, adverb and adverbial phrase errors, and adjective errors.

The results above also in line with the studies by Bitchener, 2008; Bitchener and Knoch, 2009; Vyatkina, 2010; Shintani, Ellis, and Suzuki 2014 that found that although direct written CF could improve students' accuracy the errors still made by the students' on their writing after direct written CF had been given.

It can be concluded from the results of the second research question above that direct written CF given by the teacher on low proficiency students' recount text compositions assisted low proficiency students in minimizing the errors on their recount text compositions. The direct written CF assisted students in minimizing their errors to a little extent because minimized errors just occurred on one error categories and the students still made some errors on their recount text compositions after receiving direct written $\mathrm{CF}$ from the teacher.

The results above are also in line with a study by Nasrullah (2014) that found that teacher's written CF enabled students in minimizing the grammatical errors on students' writing. In addition, findings from several previous studies that have been explained on chapter two that revealed that the direct written CF could lead to the improvement on students' writing accuracy (Bitchener, 2008; Bitchener and Knoch, 2009; Vyatkina, 2010; Shintani, Ellis, and Suzuki 2014).

It can be concluded from the results of the third research question above that direct written CF given by the teacher on average proficiency students' recount text compositions assisted average proficiency students in minimizing the errors on their recount text compositions. The direct written CF assisted students in minimizing their errors to a little extent because minimized errors just occurred on two error types and the average proficiency students still made some errors on their recount text compositions after receiving direct written CF from the teacher.

The results above are also in line with a study by Nasrullah (2014) that found that teacher's written CF enabled students in minimizing the grammatical errors on students' writing. Moreover, a study by Suarman (2013) found that medium achiever students of junior high school performed better writing accuracy after written $\mathrm{CF}$ is given by the teacher.

In addition, findings from several previous studies also revealed that the direct written CF 
could lead to an improvement in students' writing accuracy (Bitchener, 2008; Bitchener and Knoch, 2009; Vyatkina, 2010; Shintani, Ellis, and Suzuki 2014).

It can be concluded from the results of the fourth research question above that direct written CF given by the teacher on high proficiency students' recount text compositions assisted high proficiency students in minimizing the errors on their recount text compositions. The direct written CF assisted students in minimizing their errors to a medium extent because minimized errors still occurred on three types of errors and the students still made some errors on their recount text compositions after receiving direct written $\mathrm{CF}$ from the teacher.

It was in line with a study by Suarman (2013) that found that high achiever students of junior high school performed better writing accuracy after written CF is given by the teacher. The high achiever students also made fewer errors in their writing.

The results of the study found that direct written CF can assist the junior high school students on the different levels of proficiency in minimizing the errors on their recount text composition. It is in line with the previous studies about direct written CF by Bitchener, 2008; Bitchener and Knoch, 2009; Vyatkina, 2010; Shintani, Ellis, and Suzuki 2014; and Rahmawati, 2013 about the effectiveness of the direct written CF in improving students' accuracy in writing.

\section{CONCLUSION}

\section{Conclusion}

In conclusion, students of three different levels of proficiency can minimize their errors in writing after direct written CF given by the teacher although some errors still can be found. Direct written CF assists low proficiency students to a little extent in minimizing the errors on their recount text compositions. Noun and pronoun errors, action verb errors, past tense errors, conjunction errors; adverb and adverbial phrase errors; and adjective errors still be made by students. The students just did not make any errors in the time connective category.

Direct written CF assists average proficiency students to a little extent in minimizing the errors. Noun and pronoun errors, action verbs errors, past tense errors, conjunction errors, adverbs, and adverbial phrases errors still be made by students. The students just did not make any errors on the time connective and adjective category.

Direct written CF assists high proficiency students to a middle extent in minimizing the errors. Noun and pronoun errors, action verb errors, past tense errors, adverb, and adverbial phrase errors still be made by students. The high proficiency students did not make any errors in the conjunction category, time connective category, and adjective category.

Although minimized errors on students' recount text compositions were not the same among the students, yet the results of the study showed that direct written CF assisted students from three different levels of proficiency (low, average, and high) in minimizing errors on their recount text compositions.

\section{Suggestions}

There are some suggestions that the writer provides for the teacher, and further researcher in relation to direct written CF. It is important for the teacher to provide direct written CF in students' writing appropriately so students do not be confused with the feedback and they could improve their writings and avoid errors in their writing. The teacher can also provide direct written CF with a little explanation so the students can understand the errors that they made. Further researchers can also expand research related to direct written CF at university or senior high school level with different kinds of text. They can also focus on one student's proficiency level or expand their research based on students' gender. 


\section{REFERENCES}

Ary, D., Jacobs, L., \& Razavieh, A. (2010). Introduction to research in education 8th edition, Wardswoth Cengage Learning. Canada: Nelson Education Ltd Exotic Classic.

Bitchener, J. (2008). Evidence in support of written corrective feedback. Journal of Second Language Writing, 17(2), 102-118. https://doi.org/10.1016/j.jslw.2007.11.004

Bitchener, J., \& Knoch, U. (2009). The relative effectiveness of different types of direct written corrective feedback. System, 37(2), 322-329. https://doi.org/10.1016/j.system.2008.12.006

Coffin, C., Curry, M. J., Goodman, S., Hewings, A., Lillis, T., \& Swann, J. (2003). Teaching academic writing: A toolkit for higher education. Routledge.

Cornillie, F., Clarebout, G., \& Desmet, P. (2012). The role of feedback in foreign language learning through digital role playing games. Procedia-Social and Behavioral Sciences, 34, 49-53. https://doi.org/10.1016/j.sbspro.2012.02.011

DonYei, Z. (2007). Research methods in applied linguistics. Oxford University Press.

Ellis, R. (2008). A typology of written corrective feedback types. ELT Journal, 63(2), 97-107. https://doi.org/10.1093/elt/ccn023

Ellis, R. (2009). Corrective feedback and teacher development. L2 Journal, 1(1), 3-18. https://doi.org/10.5070/12.v1i1.9054

Ellis, R., Loewen, S., \& Erlam, R. (2006). Implicit and explicit corrective feedback and the acquisition of L2 grammar. Studies in Second Language Acquisition, 28(2), 339-368. https://doi.org/10/1017/S0272263106060141

Fakhrudin, F., \& Munir, A. (2014). The use of word-processing to decrease the students' errors in writing descriptive rext in SMAN 1 Babat Lamongan. RETAIN, 2(2).

Guénette, D., \& Lyster, R. (2013). Written corrective feedback and its challenges for pre-service ESL teachers. Canadian modern language review, 69(2), 129-153. https://doi.org/10.3138/cmlr.1346

Kamberi, L. (2013). The significance of teacher feedback in EFL writing for tertiary level foreign language learners. Procedia-Social and Behavioral Sciences, 70(0), 1686-1690. https://doi.org/10.1016/j.sbspro.2013.01.241

Leng, K. T. P. (2014). An analysis of written feedback on ESL students' writing. Procedia-Social and Behavioral Sciences, 123, 389-397. https://doi.org/10.1016/j.sbspro.2014.01.1437

McKenney, S., Nieveen, N., \& van den Akker, J. (2006). Design research from a curriculum perspective. Educational design research, 67-90.

Muncie, J. (2000). Using written teacher feedback in EFL composition classes. ELT Journal, 54(1), 4753. https://doi.org/10.1093/elt/54.1.47

Nasrullah. (2014). Teacher's feedback on junior high school students' interlingual errors in recount text [Post Graduate Unpublished Thesis, Universitas Negeri Surabaya]. Surabaya.

Panova, I., \& Lyster, R. (2002). Patterns of corrective feedback and uptake in an adult ESL classroom. TESOL QUARTERLY, 36(4), 573-595. https://doi.org/10.2307/3588241

Pawlak, M. (2014). Error correction in the foreign language classroom reconsidering the issues. Springer.

Rahmawati, E. (2013). Teacher's written corrective feedback and its effects on the students' rewriting errors in writing products [Post Graduate Unpublished Thesis, Universitas Negeri Surabaya]. Surabaya.

Sheen, Y., \& Ellis, R. (2011). Corrective feedback in language teaching. Handbook of research in second language teaching and learning, 2, 593-610.

Shintani, N., Ellis, R., \& Suzuki, W. (2014). Effects of written feedback and revision on learners' accuracy in using two English grammatical structures. Language Learning, 64(1), 103-131. https://doi.org/10.1111/lang.12029 
Suarman, A. (2013). The effect of feedback on student's writing accuracy. ELTIN JOURNAL, Journal of English Language Teaching in Indonesia, 1(1), 44-55.

Vyatkina, N. (2010). The effectiveness of written corrective feedback in teaching beginning German. Foreign Language Annals, 43(4), 671-689. https://doi.org/10.1111/j.19449720.2010.01108.x 